Here, indeed, we reach the rub, because the whole day's proceedings left me with the impression that most people had made up their minds beforehand and the whole programme really comprised a restatement of only too well recognized views-as opposed to a dialogue aimed at compromise or conversion.

Which is not to say that there is a clear-cut separatism between the philosophies of 'Psychiatry Rules-O.K.' and 'Autonomy for Psychology-or else'. Many conciliatory views were expressed, and Dr May Davidson, Psychologist, Warneford Hospital, made the invaluable point that in good organizations the question of interdisciplinary conflicts rarely arises: where personal relationships are good it never occurs to anyone to ask 'who should be doing what?' -one merely gets on with the job of total patient care. These moderating views were much reemphasized by the Chairmen, Professor H. Gwynne Jones and Professor Max Hamilton. Indeed, Professor Hamilton was at great pains, in his closing address, to point out how vast was our joint task, the enormous limitations of our practical knowledge, and, hence that, as matters presently stand, demarcation disputes are ludicrously superfluous. Perhaps it is in this context that Dr Davison's contribution was the most valuable because it gave us an opportunity to clear our thinking while quite rightly leaving to us the burden of solution: an edited transcript would merit separate publication.* It was intriguing that more than one member of the audience commented that they found the trend of his dissertation saddening. But perhaps this is because it accurately reflects a good deal of current-and unnecessary-bickering.

All in all, a rewarding day, but I only wish that I could have left its formal proceedings with the feeling that, if no more, attitudes had become at least a little more open, a little more fluid. However, as I hurried away, there was, in the lowering storm clouds over Durham city, an unusually brilliant rainbow. And this seemed the only truly promising portent. ...

- A modified version of Dr Davison's paper will be published in a future edition of the Bulletin.

\title{
ANNUAL SUBSGRIPTIONS
}

Members are reminded that annual subscriptions were due on I January as follows:

Fellows (United Kingdom)

Fellows (Overseas)

Members (United Kingdom)

Members (Overseas)

Affiliates (United Kingdom)

Affiliates (Overseas)
Inceptors

Corresponding Associates

Retired Members before 31.12.75

after 1.1 .76

$£ 10.00$

$£ 10.00$

$£ 4.00$

$£ 10.00$

If you have not already paid your subscription please send forthwith a cheque for the appropriate amount to the Honorary Treasurer, 17 Belgrave Square, London SWIX 8PG.

\section{WINTER QUARTERLY MEETING 1978}

\section{Preliminary Announcement}

The Winter Quarterly Meeting will be held in London and the following is the provisional programme:

Monday, 6 February (evening): Blake Marsh Lecture: Dr F. Esher.

Tuesday, 7 February: Maudsley Bequest Lectures: 'The contributions of psychology to psychiatry': (Dr J. Rachman, Perspective in behaviour modification in psychiatry; Dr D. Peck, The development and the value of the concept of personality in psychiatry; Dr E. Warrington, Organic syndromes; Dr D. Kelly, Beta blockers in psychiatry; Dr N. Yorkston, Beta blockers in schizophrenia; Dr R. Hale, title to be announced).

Wednesday, 8 February: Maudsley Bequest Lectures: (Professor M. Shepherd, Epidemiology in psychiatry; Dr M. Lipsedge, Transcultural psychiatry; Professor Sir Denis Hill, The qualities of a good psychiatrist; Dr M. Lader, Pharmacokinetics in psychiatry).

Quarterly Business Meeting. 